\title{
Spatial Mapping of Food Security in Mukim Pendang, Kedah, Malaysia
}

\author{
Tarmiji Masron \\ Universiti Sains Malaysia \\ mmiji@usm.my \\ Salfarina Abdul Gapor \\ Albukhary International University \\ salfarina@aiu.edu.my \\ Norhasimah Ismail \\ Universiti Sains Malaysia \\ shima860720@yahoo.com
}

Doi:10.5901/ajis.2014.v3n4p349

\begin{abstract}
Malaysia ranks fairly high in the Global Food Security Index, 32 out of 105 countries, which include dimensions of affordability, availability and quality to accessing food. Using the same dimensions, the paper attempts to show whether this ranking is reflected at the local level. Kedah, a state located in the northern part of Peninsular Malaysia is chosen for the case study due to high incidence of poverty, the third highest in Peninsular Malaysia. The paper is based from findings in the district of Pendang, Kedah, comparing food insecurity between three Mukim-Mukim Ayer Putih, Mukim Guar Kepayang and Mukim Bukit Raya. All three Mukim have high incidence of hard core poor, as indicated by the e-Sinar online data. The research approach is based on quantitative household survey, using the e-Sinar information as a sampling frame. A total number of 595 respondents were interviewed, 284 in Mukim Ayer Puth, 171 in Mukim Guar Kepayang and 140 in Mukim Bukit Raya. Types of food insecurity are then mapped using the GIS system to analyse the distribution and trends of food insecurity over the study area.
\end{abstract}

Keywords: Food security, GFSI, GIS

\section{Introduction}

Food security can be defined as a state when all people at all times have access to sufficient, safe, nutritious food to maintain a healthy and active life (FAO, 2012). In other words, food security exists when all people at all times have physical and economic access to sufficient, safe and nutritious food to meet their dietary needs and food preferences for an active and healthy life (Anderson, 2009). This definition has widely established the four pillars of food security: availability, accessibility, utilization and stability. Food security is today a big issue not only due to food production and hunger but also other factors such as population pressures, food prices, climate change and disparities of wealth and income. The issue of food security now has become more alarming, as a result of failure for modernity approach as clearly presented by the green revolution technology to resolve food insecurity problems such as famine and malnutrition, particularly in the developing countries.

The concept and definition of food security have changed since it is first introduce in the early 1940s. Later in 1970s, the definition of food security was developed from the perspective of food-supply to ensure that all people everywhere have enough food to eat. The importance of consumption and access has been put forward through the concept of entitlement (Sen, 1981). The concept of food security started when FAO was established in 1945 and the rights to food as basic needs was recognized under the Universal declaration of Human Rights in 1948. By 1963, the first World Food Program was established. This was consequently followed by conferences and summit to promote food security such as World Food Summit in 1996 and the World Food Summit in 2002.

In terms of issues, the discussion of food security has evolved from merely focusing on global food crisis, food supply problems institutional arrangements covering information, resources for promoting food security and forums for dialogue on policy issues. This is followed by the issues of famine and hunger which include the vulnerability as part of 
the main factors under food insecurity. The failure of modernity, as represented by the Green Revolution was also highlighted as the result of lack of effective demand. By the 1990s, protein-energy malnutrition is highlighted, including food safety, nutritional balance and promoting active and healthy lifestyle. Hence the concept and discussion in food security has evolved from focusing on national production to individual and household consumption; from entitlement theory to livelihoods perspective; from result indicators to process indicators and towards rights based approach to food security. Food insecurity has been linked to poverty, disaster prone areas and even to modern lifestyle and worldview (Ejeta, 2009).

Achieving food security remains a complex issue since it cross various sectors such as agriculture, trade, health and environment and also affected by ongoing issues such as climate change, conflicts, disasters, urbanization and etc. By considering the inter-relatedness between sectors, three pillars which affecting the food security known as utilization of food, accessibility to food and availability of food (Faal, 2010; Syed Najmul \& Adnan, 2012) (Figure 1). In order to enhance food security, various organizations such as United Nation (UN), Food and Agriculture Organization (FAO), International Fund for Agricultural Development (IFAD) and World Food Programme (WFP) continue to harness tremendous resources in the search for long-term measures to stimulate agriculture, rural development and sustainable livelihoods towards food.

Figure 1: Three pillars of food security

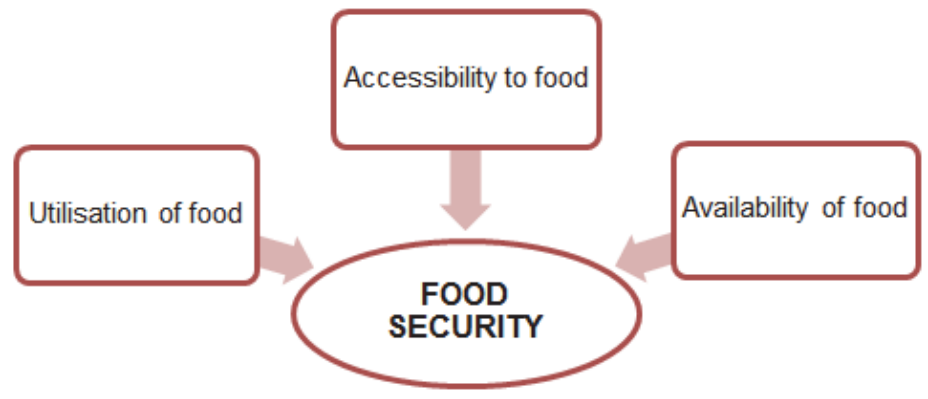

Modified from: Faal, 2010

In 2002 until 2004, approximately 864 million people or 14\% of the world population were undernourished results in human suffering, disease and mortality limits neurological development, reduces labor productivity and hold back nation's economic growth (FAO, 2006). Chronic food shortages lead to compromised human well-being, hunger and malnutrition which posing serious challenges to institution both government and non-government also to policy and decision makers at all levels (Misselhorn, 2005).

Global Food Security Index (GFSI)

The Global Food Security Index (GFSI) is a dynamic benchmarking model that uses quantitative and qualitative indicators to provide a standard against which countries can be measured and reveal individual country's strengths and weaknesses (http://foodsecurityindex.eiu.com/) in food security indicators. The GFSI is published by the Economist Intelligence Unit and attempts to measure the risks of food insecurity, particularly following the food riots in 2008 and 2011. GFSI provides ranking of food security for 105 countries including high and low income countries. The index is based on a consistent framework and assesses food security across three dimensions: affordability (which is similar to the notion of accessibility under the FAO definition of FNS), availability and utilization.

The source data of the GFSI are based on existing research on food security, including FAO's Annual State of Food Insecurity in the World report, the GHI published by IFPRI, and other documents. Each dimension of the GFSI is measured by comprehensive FNS indicators as detailed in Table 1. The indicators are normalized and then aggregated across categories which enables cross country comparisons. There are two sets of weights applied in the model: neutral weights and expert weights. Unlike the GHI which only focuses on emerging economies, middle and low income countries, the GFSI also assesses the affordability, availability and quality of food in developed countries. 
Table 1: GFSI Category

\begin{tabular}{|c|c|l|}
\hline No. & Category & \multicolumn{1}{c|}{ Details } \\
\hline 1 & Affordability & $\begin{array}{l}\text { Measures the ability of consumers to purchase food, their vulnerability to price shocks, and the } \\
\text { presence of programs and policies to support them when shocks occur. }\end{array}$ \\
\hline 2 & Availability & $\begin{array}{l}\text { Measures the sufficiency of the national food supply, the risk of supply disruption, national } \\
\text { capacity to disseminate food, and research efforts to expand agricultural output. }\end{array}$ \\
\hline 3 & $\begin{array}{c}\text { Quality \& } \\
\text { Safety }\end{array}$ & $\begin{array}{l}\text { Measures what is sometimes called "utilization" in food security parlance. It assesses the variety } \\
\text { and nutritional quality of average diets, as well as the safety of food. }\end{array}$ \\
\hline
\end{tabular}

Table 2: Indicators of GFSI

\begin{tabular}{|c|c|c|}
\hline Affordability & Availability & Quality \& Safety \\
\hline $\begin{array}{l}\text { Food consumption as a } \\
\text { proportion of total household } \\
\text { expenditure }\end{array}$ & $\begin{array}{l}\text { Sufficiency of supply } \\
\text { - Average food supply in kcal/capita/day } \\
\text { - Dependency on chronic food aid }\end{array}$ & Diet diversification \\
\hline $\begin{array}{l}\text { Proportion of population living } \\
\text { under the global poverty line }\end{array}$ & $\begin{array}{l}\text { Public expenditures on agriculture research } \\
\text { and development }\end{array}$ & $\begin{array}{l}\text { National standards } \\
\text { - National dietary guidelines } \\
\text { - National nutrition plan or strategy } \\
\text { - Nutrition monitoring and surveillance }\end{array}$ \\
\hline $\begin{array}{l}\text { GDP per capita (at purchasing } \\
\text { power parity, or PPP, exchange } \\
\text { rates) }\end{array}$ & $\begin{array}{l}\text { Agriculture infrastructure } \\
\text { - Existence of adequate storage facilities } \\
\text { - Road infrastructure } \\
\text { - Port infrastructure }\end{array}$ & $\begin{array}{l}\text { Micronutrient availability } \\
\text { - Dietary availability of vitamin A } \\
\text { - Dietary availability of animal iron } \\
\text { - Dietary availability of vegetal iron }\end{array}$ \\
\hline Agricultural import tariffs & Volatility of agricultural production & Protein quality \\
\hline $\begin{array}{l}\text { Presence of food safety net } \\
\text { programmes }\end{array}$ & Political stability risk & $\begin{array}{l}\text { Food safety } \\
\text { - Agency to ensure the safety and health of food } \\
\text { - Percent of population with access to potable } \\
\text { water } \\
\text { - Presence of formal grocery sector } \\
\end{array}$ \\
\hline Access to financing for farmers & & \\
\hline
\end{tabular}

Source: Economist Intelligence Unit, 2012

Under the GFSI, Malaysia's performance is fairly high, 32 out of 105 countries and making herself leaders in the Southeast Asian region for food security. According to the ranking, Malaysia's strengths (score over 75) are in 6 indicators-nutritional standards (100\%), proportion of population under global poverty line $(97.6 \%)$, volatility of agricultural production (87.8\%), food safety (87.5\%), agricultural import tariffs (84.2\%) and prevalence of undernourishment (84.2\%). Nutritional standards and food safety is under the category of quality and safety. Proportion of population under global poverty line is under affordability while prevalence of undernourishment is under availability. Malaysia weaknesses are in the category of affordability and availability. Under the category of affordability, Malaysia lack food safety net program and financing programmes for farmers compared to other better off countries in terms of food security.

Under the category of availability, Malaysia's agricultural infrastructure does not promote food security, for example in terms of crop storage facilities score 0 . Hence the results are mixed with more rooms for improvement to achieve food security. Despite the positive result of the GFSI, and effort done by the Malaysian government to achieve security, Malaysia is still not self-sufficient especially in the production of her staple food, rice production. This situation has become seriously alarming during the 2008 world food crisis, when major rice exporting countries banned or limited the export of rice to Malaysia. Thus, the objective for full rice sufficiency needs to be achieved by year 2015. Attaining this is difficult if the rice producers fail to cope with the impacts of food insecurity. This is further worsened by climate change causing crop failures. Hence, this paper looks at the trend of food insecurity in Kedah, focusing on the MADA areas of Pendang, Kedah. 


\subsection{GIS in Food Security Study}

A geographic information system (GIS) integrates hardware, software, and data for capturing, managing, analysing, and displaying all forms of geographically referenced information (Burrough, 1986). GIS allows us to view, understand, question, interpret, and visualize data in many ways that reveal relationships, patterns, and trends in the form of maps, globes, reports, and charts. A GIS helps answer questions and solve problems by looking at data in a way that is quickly understood and easily shared. GIS technology can be integrated into any enterprise information system framework. GIS technology is an important tool for the advancement and sustainability of food production to support the survival of the peoples (ESRI, 2008).

Increasingly, GIS is able to assist in allaying the confusion and presenting a more comprehensive way of sorting through the information (Cruse, 2013). GIS gives people the geographic advantage to become more productive, more aware and more responsive citizens of our environment. GIS and spatial analysis have been in a productive relationship over the past decades (Goodchild, et al., 1992). GIS has been seen as the crucial factor in implementing methods of spatial analysis which making them more accessible to a broader range of users and more widely used in making effective decisions and in supporting scientific research.

According to Devereux, et al., (2004), the combination of the small-sample estimates of poverty produced by implementation of Geographic Information System (GIS) and other mapping software was a way of displaying information about the spatial distribution of ill-being which was much more accessible to policy-makers and other users than conventional statistical tables. There are a few studies of GIS implementation and food related field such as food security, food consumption and others. Furthermore, by overlaying maps of the geographic factors which associated with poverty and vulnerability (such as terrain, agro-ecological zone, distance from major cities, or occurrence of natural disasters) on a base poverty map, it can be particularly helpful in identifying the causal factors which underlying the spatial distribution of food insecurity and vulnerability.

Study by Morrison, et al. (2011) present a unique method of using the spatial nutrition survey data to evaluate differences consumption between age groups and genders and the result showed that, there were considerable variation in consumption of each food group based on these demographic differences. There is also study which utilized a geographic information system (GIS) to represent and analyze the spatial characteristics of food security in Worcester (Allen, et al., 2012). The used of GIS were implemented for issues considered such as location of food sources by type (e.g. supermarkets, corner stores, and fast food), availability of healthy foods, food prices, available transportation options, as well as socioeconomic variables from the 2010 census, such as household income, race and ethnicity.

Mapping spatial method also has not been regularly incorporated into previous agriculture and food security research but there are many study used this mapping spatial to represent the result especially in socio-economic study. There are more recent studies such as Lopez-Class \& Hosler (2010), Haering \& Franco (2010), and Franco, et al., (2008) chose to use GIS to represent socio-economic variables from the U.S. Representing information visually makes it more intuitive. Haering \& Franco (2010) use this method in mapping the locations of different store types in the city of Baltimore. In addition to simply acting as a visual aid, GIS acts as a powerful tool for examining socio-economic variables with respect to location.

Furthermore, GIS can be used to perform spatial-statistical analyses ranging from simple percentage calculations using U.S. Census demographic data to more complicated statistical tests. Meenar \& Hoover (2011) applied GIS based spatial analysis to find neighborhoods that face the issues of food insecurity, which included data analysis on food cupboards, community gardens, urban farms, supermarkets, farmers markets, grocery stores, convenience stores, and data collected by the Southeastern Pennsylvania Household Health Survey. In this study, the used of mapping spatial method will help in establish clear idea on food security in Pendang, Kedah.

\section{Methodology}

\subsection{Study Area}

Kedah, despite being one of the rice bowls in Malaysia has one of the highest incidences of poverty in Malaysia. Kedah has the fifth highest incidence of poverty after Sabah, Terengganu, Kelantan and Sarawak in Malaysia. In Peninsular Malaysia, Kedah has the third highest incidence of poverty after Terengganu and Kelantan. According to the 2004 statistics on poverty, the average household size of Kedah is 4.6, with an overall incidence of poverty at 7.0 per cent and incidence of hard core poverty of 1.3 per cent (Ninth Malaysia Plan, 2005). Pendang is a district in Kedah with eight 
districts namely Mukim Tobiar, Mukim Padang Pusing, Mukim Guar Kepayang, Mukim Padang Peliang, Mukim Rambai, Mukim Bukit Raya, Mukim Padang Kerbau and Mukim Air Puteh. Kedah had developed one system to identify, document and to some extend help poor people by developing a database of the poor in a portal known as e-SINAR. Applicant that qualified to register is head of the household, Malaysian citizen and resident of Kedah with family's monthly income of RM 720 below or per capita RM 180 below. Based on the e-Sinar data, Pendang has 1252 poor whereby 379 are poor and 873 hard core poor. The study is motivated by the assumption that most of the poor have food insecurity problems. Yet, it is ironic that, these are the same groups that produce staple food for the nation.

Figure 2: Study area; (a) Kedah states, (b) Pendang district

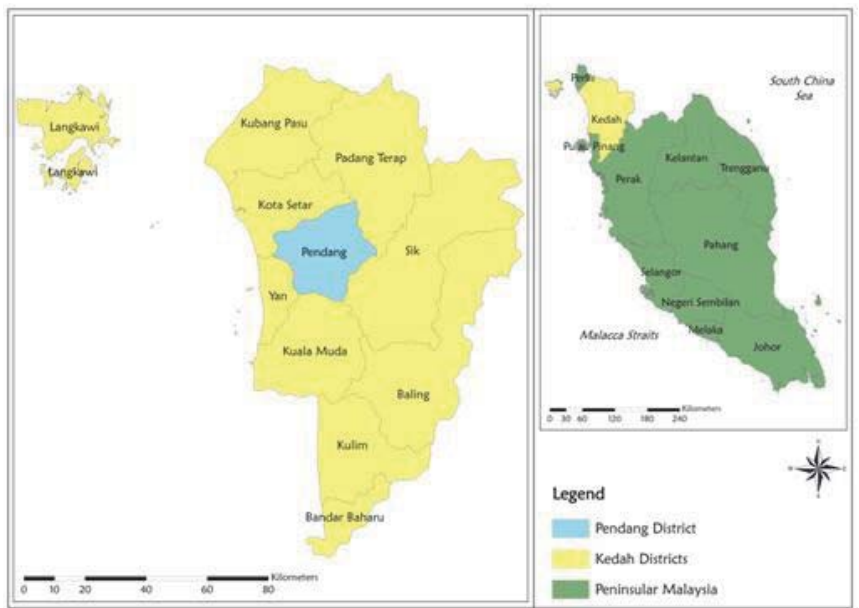

\subsection{Questionnaires Design}

Three mukim in the district of Pendang are chosen due to the high number of poor households in these areas. The three mukim are Guar Kepayang, Bukit Raya and Ayer Putih. The respondents are chosen based from the e-Sinar poverty database and lists from the Head of the Village Committee in Mukim Bukit Raya, there are 140 respondents from 16 villages, whereas for Mukim Ayer Putih with a total respondents of 284 from 35 villages. Mukim Guar Kepayang has 171 respondents covering 20 villages. The research uses a quantitative approach through a household survey by interviewing the head of the household.

The questionnaires design is based on the latest United States Department of Agricultural (USDA) questionnaires under the Current Population Survey (CPS) Food Security Supplement revised in 2000 but modified according to local issues and problems to measure household food security. The questionnaires aim to inquire about household conditions, events, behaviour and subjective reaction such as; anxiety experienced by respondents that food budget or supply may be insufficient to meet basic needs; experience of running out of food, without money to obtain more; respondents' perception on the quantity and quality food intake; consequences of reducing food intake and the physical sensation of hunger or loss of weight for the respondents and specifically for their children.

There are three conditions related to food security issues attempted to be revealed from the questionnaires -the conditions of being food secured without hunger, food insecured with hunger (moderate), and food insecured with hunger (extreme cases). Food secured without hunger means little or no reduction in member's food intake, adequate supply of food with some food management, such as reduced quality of food and increase unusual coping patterns. Food insecured with hunger (moderate) means that food intake has been reduced causing hunger but not observed in children. Food insecured with hunger (severe) means everyone including children experienced hunger and at the stage of severity. The findings are then mapped using GIS to show the spatial trend of food insecurity pattern.

\subsection{GIS Data Collection and Analysis}

Data collection method in GIS is divided into secondary data and primary data. Secondary data are obtained from 
previous studies, library research GIS Laboratory and resource room (article, analog map and internet material). Primary data are obtained from field work done in the site using geographic information technologies such as GIS and GPS. Field studies are done to determine the exact location of the study area by using the Global Positioning System (GPS) in the form of accurate location coordinates. Basically, by using GIS, the data is divided in two - spatial and non-spatial. The foundation for the geodatabase (non-spatial) was primarily developed using ArcGIS software. Points were defined by geographic data, that is, station point with spatial co-ordinates. This process proved to be a dynamic way in which to add to the geodatabase so that it could grow over time in according with new data. The last step from this is producing the map.

Figure 3: Methodology diagaram

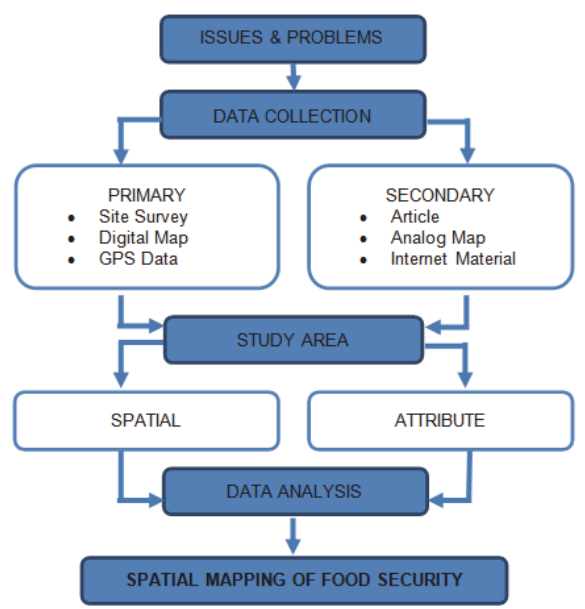

\section{Results \& Discussion}

\subsection{Demographic Profiling of Respondents}

Most of the respondents are male (60.67\%) and married (66.05\%) with low education attainment, mainly only finishing Primary School (40.50\%) (Figure 4). Most of the respondents are working (65.55\%) as rubber tapers (25.89\%) and farmers (25.13\%). Table 6 showed monthly income, expenditure and average income (alternative employment). Based on the result, the highest income recorded is RM 2, 629.00 while some respondents have no income. Mean of income is based on 25\% percentiles (RM 300.00). Mean of expenditure is based on 25\% percentiles which is RM 300.00 per month. Some of the respondents have alternative employment to support their family. The highest alternative employment income recorded is RM 2,000.00 and the lowest RM 5. Mean of alternative employment income based on $25 \%$ percentiles (RM 100.00).

Figure 4: Respondents demographic profile

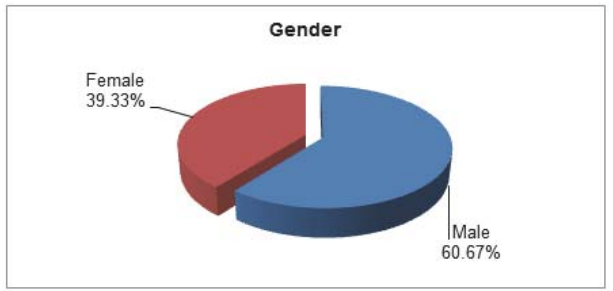



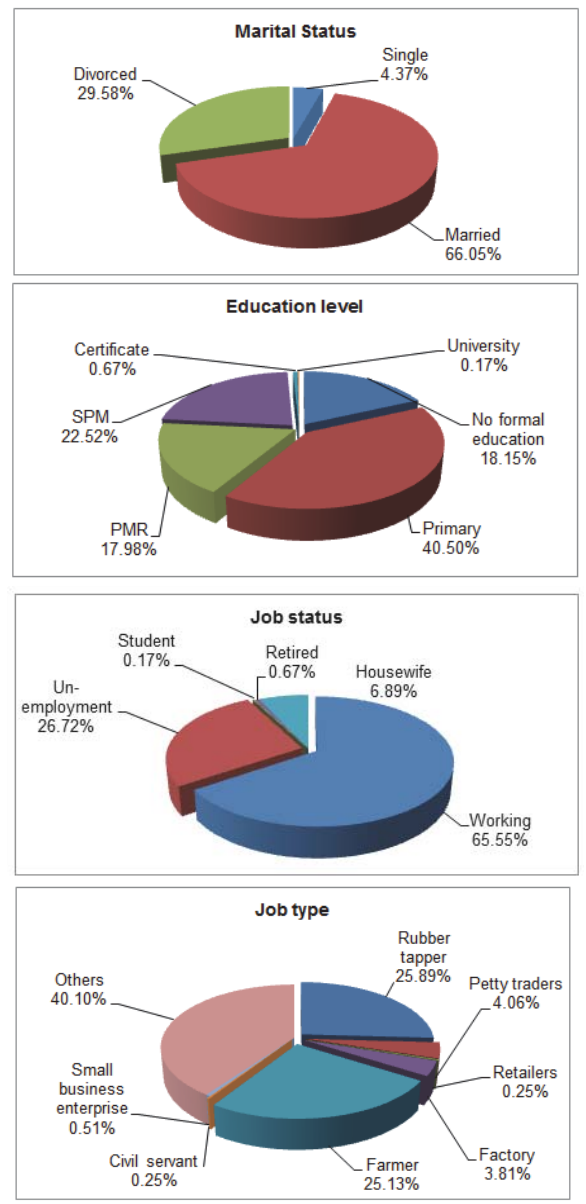

Table 3: Income, expenditure and average income of respondent

\begin{tabular}{|l|c|c|c|c|}
\hline \multicolumn{2}{|c|}{} & Monthly income (RM) & Monthly Expenditure (RM) & Average alternative income (RM) \\
\cline { 2 - 5 } \multicolumn{1}{|c|}{$\mathrm{N}$} & Valid & 565 & 561 & 85 \\
\hline Mean & & 30 & 34 & 510 \\
\hline Median & & 494.86 & 472.91 & 240.41 \\
\hline Mode & & 500.00 & 450.00 & 200.00 \\
\hline Std. Deviation & & 264.537 & 500 & 200 \\
\hline Minimum & & 0 & 248.309 & 5 \\
\hline Maximum & & 2629 & 15 & 2000 \\
\hline \multirow{3}{*}{ Percentage } & 25 & 300.00 & 300.002 & 100.00 \\
\cline { 2 - 5 } & 50 & 500.00 & 635 & 200.00 \\
\cline { 2 - 5 } & 75 & 600.00 & 450.00 & 300.00 \\
\hline
\end{tabular}

Figure $5 \mathrm{a}$ shows that the youngest respondent is 19 years old while the oldest is 95 years old. The average age is 54.52 years old. The minimum and maximum height for respondent is 121 and $185 \mathrm{~cm}$ respectively with the average of 161.29 $\mathrm{cm}$. (Figure $5 \mathrm{~b}$ ). Figure $5 \mathrm{c}$ represented the weight of respondent as 30 and $92 \mathrm{~kg}$ for minimum and maximum weight respectively with the average of $60.8 \mathrm{~kg}$. For the Body Mass Index (BMI) (Figure $5 \mathrm{~d}$ ) shows that the lowest BMI is 14 while 36 are the highest with an average of 23.37. From the BMI result, most of the respondents are of ideal weight. Small percentages are obese or underweight. 
Figure 5: Frequency of (a) age, (b) height, (c) weight and (d) body mass index of respondents

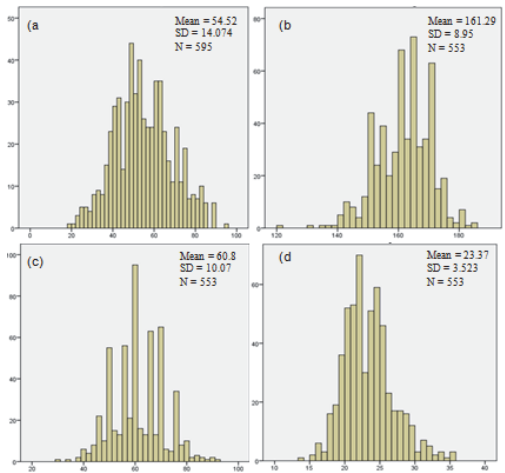

Figure 6 and 7 illustrated Geographic Information System (GIS) for food security in the district of Pendang, Kedah. Majority of the respondents in Pendang is in the category of "enough food but not always the kind of food wanted" situation followed by "sometimes not enough to eat" and "often not enough" (Figure 7). The spatial trend shows no clear pattern, those households with "often not enough" foods are isolated in the South-east of Ayer Putih, in south of Bukit Raya and south of Guar Kepayang.

Figure 6: Geographic Information System (GIS) for food security in the district of Pendang

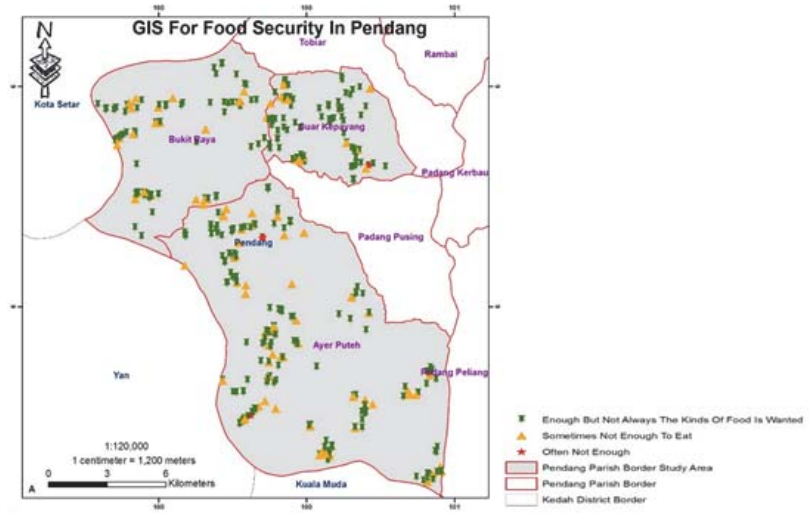

Figure 7: Bar graph of food security distribution in study area

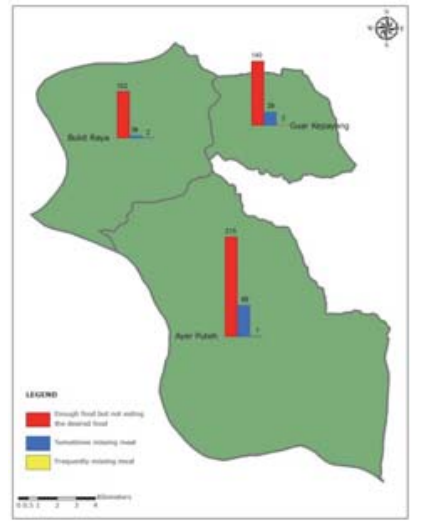


Figure 8: Percentage of food security pattern in Pendang

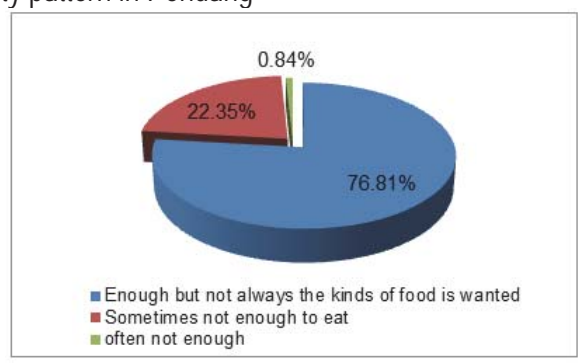

From the result, it showed that 102 respondents are in the situation "enough but not always the kind of food wanted" followed by 36 respondents in the situation "sometimes not enough to eat" and only 2 respondents from Kampung Kubang Kuar in "often not enough" category (Figure 8a). The villages with the highest "sometimes not enough to eat" category are Kampung Kubang Anak Gajah, Kampung Alur Besar and Kampung Rambai. Meanwhile in Mukim Guar Kepayang, 140 respondents are in the situation "enough but not always the kind of food wanted" followed by 29 respondents in the category of "sometimes not enough to eat" and only 2 respondents in the category of "often not enough" (Figure 8b). The two households under the category of "often not enough" to eat are in Kampung Charuk Kudung and Kampung Bahagia, whereas many of the households under the category of "sometimes not enough to eat" are mainly at Kampung Majapahit.

Lastly, in Mukim Ayer Putih, 215 respondents are in the situation "enough but not always the kind of food is wanted" followed by 68 respondents in the category "sometimes not enough to eat" and only 1 respondents in the category of "often not enough" to eat (Figure 8c). The only household under the category of "often not enough" to eat is at Kampung Sungai Baru while most households under the category "sometimes not enough to eat" are at Kampung Paya Mengkuang, followed by Kampung Pokok Tai and Kampung Sungai Baru. It can be concluded that, Mukim Guar Kepayang presented the highest percentage in "enough but not always the kinds of food wanted" situation, followed by Mukim Ayer Putih and Mukim Bukit Raya. In situation of "sometimes not enough to eat", Mukim Bukit Raya showed the maximum percentage followed by Mukim Ayer Putih and Mukim Guar Kepayang. Mukim Bukit Raya illustrated the highest percentage in "often not enough" situation followed by Mukim Guar Kepayang and Mukim Ayer Putih.

Figure 10 showed the concentration map of food security in Pendang. For the the 'Enough food but not eating the desired food' categories, Mukim Gua Kepayang and Bukit Raya showed higher respondent compare to Mukim Ayer Puteh (Figure 10(a)). In 'sometimes missing meal' categories, Mukim Ayer Puteh showed the highest respondent present in this categories followed by Mukim Bukit Raya and lastly, Mukim Gua Kepayang. Figure 10(c) for 'Frequently missing meal' categories showed the same situation like in Figure 10 (b) except the second higher was Mukim Gua Kepayang and followed by Mukim Bukit Raya.

Figure 9: Percentage of the food situation in the household in; (a) Mukim Bukit Raya, (b) Mukim Guar Kepayang, (c) Mukim Ayer Putih

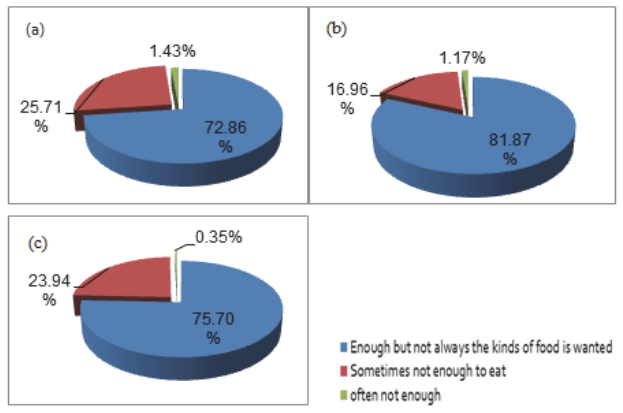

Figure 10: Map of food security distribution in each mukim, (a) Enough food but not eating the desired food, (b) Sometimes missing meal, (c) Frequently missing meal 


\section{Conclusion}
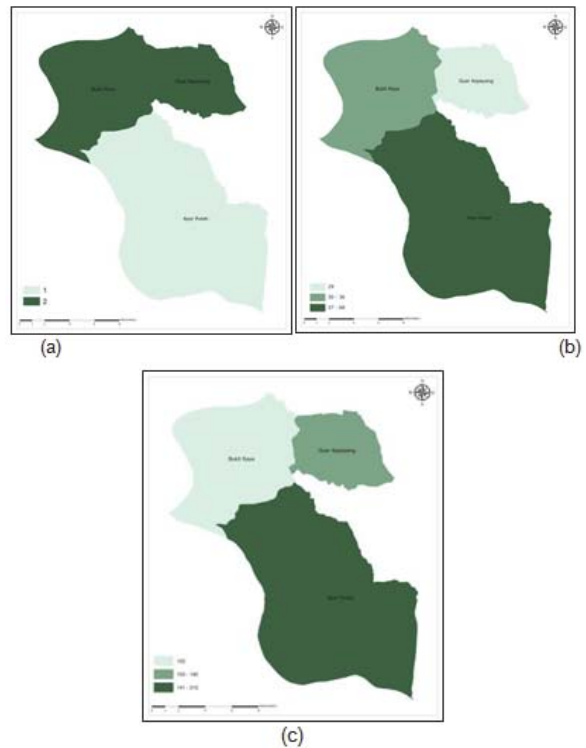

The spatial pattern of food security shows no concentration in one specific area, with those households under the category "enough but not always the kinds of food wanted" and "sometimes not enough to eat" clustered in similar areas. However households under the category of "often not enough food" are mainly in Bukit Raya, followed by Guar Kepayang and Ayer Putih. The findings indicate that majority of the respondent's food requirement are met daily but the types of food consumed are not to their wish but merely to their affordability. A comparative analysis shows that there is no difference in incidence of frequently not having enough food in all the three Mukim. Spatial distribution shows no concentrated areas experiencing food insecurity, with very low incidence of often not enough food. The spatial pattern shows pockets of food insecurity. Hence, spatial trend shows that the GFSI is also reflected by the local trends and type of food insecurity. Through these findings, agencies responsible for alleviating poverty and ensuring food security can focus on the villages and areas identified. Further study should be done to identify the causes of food insecurity in the respective villages identified.

\section{Acknowledgement}

"The authors would like to extend their appreciation to the Universiti Sains Malaysia for the Exploratory Research Grantt Scheme (ERGS), entitled "Mapping \& Identifying Vulnerable Groups To Food Insecurity Using Vulnerability And Adaptability (V\&A) Methods: Case Study Of Paddy Area In MADA And Non-MADA Area Kedah" [Grant No. 203/PHUMANITI/6730030] that makes this study and paper possible."

\section{References}

Allen, D., Filice, J., Patel, N. \& Warner, B. (2012). Analyzing food security in Worcester. Worcester Food Policy and Active Living Council (WFPALC).

Anderson, P. P. (2009). Food security: Definition and measurement. Food Security, 5-7.

Burrough, P. A. (1986), Principles of Geographic Information Systems for Land Resources Assessment. Clarendon Press, Oxford.

Cruse, M. (2013, July 05). Geographic Information Systems (GIS) and Food Security. Retrieved November 20, 2013, from Hungerundernutrition: http://www.hunger-undernutrition.org/blog/2013/05/geographic-information-systems-gis-and-food-security.html

Devereux, S., Baulch, B., Hussein, K., Shoham, J., Sida, H., \& Wilcock, D. (2004). Food insecurity measurement, livelihoods approaches And policy: applications in fivims. Food Insecurity and Vulnerability Information and Mapping Systems (FIVIMS) Secretariat.

Economist Intelligence Unit. (2012). The global food security index 2012: An assessment of food affordability, availability and quality. London: The Economist.

ESRI (2008). GIS best practices: GIS for Sustainable Agriculture. Retrieved from http://www.esri.com/library/bestpractices/sustainable- 
agriculture.pdf

Faal, J. (2010, October). Mapping food: Painting the right picture. ict4d article.

Food and Agriculture Organization (2006) FAOSTAT: FAO statistical databases. Food and Agriculture Organization of the United Nations, Rome.

Food and Agriculture Organization of the United Nations. (2012). Support to the EU Programme on Linking Information and DecisionMaking to Improve Food Security for Selected Greater Mekong Sub-Regional Countries. Rome, Italy: Office of Evaluation.

Franco, M., Diez Roux, A. V., Glass, T. A., Caballero, B., \& Brancati, F. L. (2008). Neighborhood characteristics and availability of healthy foods in Baltimore. American Journal of Preventive Medicine, 35(6), 561-567.

Goodchild, M. F., Haining, R. P., Wise, S. (1992). Integrating GIS and spatial analysis: problems and possibilities.International Journal of Geographical Information Systems6: 407-23

Haering, S. A., \& Franco, M. (2010). The Baltimore City food environment. Retrieved from

http://www.jhsph.edu/clf/PDF_Files/BaltimoreCityFoodEnvironment.pdf

Lopez-Class, M., \& Hosler, A. S. (2010). Assessment of community food resources: A latino neighborhood study in upstate New York. Journal of Poverty, 14, 369-381. doi:10.1080/10875549.2010.517070

Meenar, M. \& Hoover, B. (2011).Food Insecurity and Spatial Inequality in Philadelphia's Lower-Income Neighborhoods: Analyzing the Role of Community Gardens. Center for Sustainable Communities Temple University.

Misselhorn, A. A. (2005). What drives food insecurity in Southern Africa? a meta-analysis of household economy studies. Global Environmental Change, 15, 33-43.

Morrison, K. T., Nelson, T. A. \& Ostry, A. S. (2011). Mapping spatial variation in food consumption. Applied Geography, $1262-1267$.

Sen, A. (1981). Poverty and Famine: an Essay on Entitlement and Deprivation. New York: Oxford University Press.

Syed Najmul, I. H., \& Adnan, U. (2012). Spatial pattern of food security in Eastern Uttar Pradesh, India. Asia-Pacific Journal of Social Sciences, 131-150.

\section{APPENDICES}

Overall GFSI Ranking

Appendix 1 Overall GFSI ranking for 2013

\begin{tabular}{|c|c|c|c|c|c|c|c|c|}
\hline Rank & Countary & $\begin{array}{c}\text { Score/ } \\
100\end{array}$ & Rank & Countary & $\begin{array}{c}\text { Score/ } \\
100\end{array}$ & Rank & Countary & $\begin{array}{c}\text { Scorel } \\
100\end{array}$ \\
\hline 1 & United States & 86.8 & 37 & Slovakia & 63.2 & 73 & Uzbekistan & 40.9 \\
\hline 2 & Norway & 86.5 & 38 & Turkey & 62.9 & 74 & Myanmar & 40.1 \\
\hline 3 & France & 83.7 & 39 & South Africa & 61.0 & 75 & Pakistan & 39.7 \\
\hline 4 & Austria & 83.4 & 40 & Russia & 60.9 & 76 & Cote d'Ivoire & 39.5 \\
\hline$=5$ & Switzerland & 83.2 & 41 & Venezuela & 60.8 & 77 & Uganda & 38.3 \\
\hline$=5$ & Netherlands & 83.2 & 42 & China & 60.2 & 78 & Cameroon & 36.9 \\
\hline 7 & Belgium & 82.4 & 43 & Botswana & 60.0 & 79 & Syria & 36.7 \\
\hline 8 & Canada & 82.1 & 44 & Panama & 59.7 & 80 & Kenya & 36.4 \\
\hline 9 & New Zealand & 82.0 & 45 & Thailand & 58.9 & 81 & Bangladesh & 35.3 \\
\hline 10 & Denmark & 81.8 & 46 & Belarus & 58.8 & 82 & Senegal & 34.5 \\
\hline$=11$ & Ireland & 81.7 & $=47$ & Ukraine & 58.0 & 83 & Tajikistan & 34.2 \\
\hline$=11$ & Germany & 81.7 & $=47$ & Tunisia & 58.0 & 84 & Nepal & 33.8 \\
\hline 13 & Finland & 81.4 & 49 & Serbia & 56.8 & 85 & Benin & 33.7 \\
\hline 14 & Sweden & 80.8 & 50 & Peru & 56.0 & 86 & Nigeria & 33.0 \\
\hline 15 & Australia & 80.1 & 51 & Bulgaria & 55.9 & 87 & Guinea & 32.0 \\
\hline 16 & Singapore & 79.9 & 52 & Colombia & 54.5 & 88 & Angola & 31.8 \\
\hline 17 & Israel & 78.4 & 53 & Paraguay & 52.9 & 89 & Cambodia & 31.3 \\
\hline 18 & Japan & 77.8 & 54 & Jordan & 52.3 & 90 & Ethiopia & 31.2 \\
\hline 19 & Spain & 77.5 & 55 & Dominican Republic & 51.9 & 91 & Niger & 30.1 \\
\hline 20 & United Kingdom & 77.3 & 56 & Egypt & 51.7 & 92 & Burkina Faso & 29.9 \\
\hline 21 & Portugal & 76.1 & 57 & Ecuador & 51.6 & $=93$ & Yemen & 29.6 \\
\hline 22 & Italy & 74.6 & 58 & Kazakhstan & 51.4 & $=93$ & Mozambique & 29.6 \\
\hline 23 & Czech Republic & 72.2 & 59 & Morocco & 49.4 & 95 & Tanzania & 29.4 \\
\hline 24 & South Korea & 71.1 & $=60$ & Sri Lanka & 48.6 & $=96$ & Madagascar & 29.3 \\
\hline 25 & Greece & 70.7 & $=60$ & Vietnam & 48.6 & $=96$ & Rwanda & 29.3 \\
\hline 26 & Chile & 70.3 & 62 & Honduras & 48.4 & 98 & Sierra Leone & 29.0 \\
\hline 27 & Poland & 69.9 & 63 & El Salvador & 47.5 & 99 & Malawi & 28.3 \\
\hline
\end{tabular}




\begin{tabular}{|c|c|c|c|c|c|c|c|c|}
\hline Rank & Countary & $\begin{array}{c}\text { Score/ } \\
\mathbf{1 0 0}\end{array}$ & Rank & Countary & $\begin{array}{c}\text { Score/ } \\
\mathbf{1 0 0}\end{array}$ & Rank & Countary & $\begin{array}{c}\text { Score/ } \\
\mathbf{1 0 0}\end{array}$ \\
\hline 28 & Hungary & 69.0 & 64 & Philippines & 46.9 & 100 & Zambia & 28.1 \\
\hline 29 & Brazil & 67.0 & 65 & Bolivia & 46.2 & 101 & Haiti & 27.6 \\
\hline 30 & Mexico & 66.2 & 66 & Indonesia & 45.6 & 102 & Mali & 26.8 \\
\hline 31 & Saudi Arabia & 65.7 & 67 & Ghana & 45.4 & 103 & Burundi & 26.3 \\
\hline 32 & Uruguay & 65.3 & $=68$ & Algeria & 45.2 & 104 & Sudan & 25.2 \\
\hline 33 & Romania & 65.0 & $=68$ & Guatemala & 45.2 & 105 & Togo & 22.7 \\
\hline 34 & Malaysia & 64.5 & 70 & India & 44.4 & 106 & Chad & 22.1 \\
\hline 35 & Argentina & 63.8 & 71 & Azerbaijan & 43.1 & 107 & Congo (Dem. Rep.) & 20.8 \\
\hline 36 & Costa Rica & 63.7 & 72 & Nicaragua & 41.6 & & & \\
\hline
\end{tabular}

Appendix 2 Overall GFSI ranking for 2012

\begin{tabular}{|c|c|c|c|c|c|c|c|c|}
\hline Rank & Countary & $\begin{array}{c}\text { Scorel } \\
100\end{array}$ & Rank & Countary & \begin{tabular}{|c|} 
Scorel \\
100
\end{tabular} & Rank & Countary & $\begin{array}{c}\text { Scorel } \\
100\end{array}$ \\
\hline 1 & United States & 89.5 & 36 & Turkey & 63.7 & 71 & Uganda & 41.9 \\
\hline 2 & Denmark & 88.1 & 37 & Serbia & 63.2 & 72 & Uzbekistan & 40.8 \\
\hline 3 & Norway & 88.0 & $=38$ & Romania & 62.5 & 73 & Algeria & 40.5 \\
\hline 4 & France & 86.8 & $=38$ & China & 62.5 & 74 & Cameroon & 38.6 \\
\hline 5 & Netherlands & 86.7 & 40 & South Africa & 61.7 & 75 & Pakistan & 38.5 \\
\hline 6 & Austria & 85.6 & 41 & Venezuela & 61.6 & 76 & Cote d'Ivoire & 38.0 \\
\hline 7 & Switzerland & 83.7 & 42 & Panama & 59.7 & 77 & Kenya & 37.6 \\
\hline 8 & Canada & 83.4 & 43 & Belarus & 58.5 & 78 & Myanmar & 37.2 \\
\hline 9 & Finland & 83.1 & 44 & Ukraine & 58.4 & 79 & Nepal & 35.2 \\
\hline 10 & Germany & 83.0 & 45 & Thailand & 57.9 & 80 & Nigeria & 34.8 \\
\hline 11 & New Zealand & 82.7 & 46 & Bulgaria & 57.6 & 81 & Bangladesh & 34.6 \\
\hline 12 & Belgium & 82.2 & 47 & Botswana & 56.5 & 82 & Benin & 34.1 \\
\hline 13 & Spain & 81.2 & 48 & Peru & 53.6 & 83 & Yemen & 33.3 \\
\hline 14 & Australia & 81.1 & 49 & Paraguay & 52.8 & 84 & Tajikistan & 32.3 \\
\hline 15 & Portugal & 80.8 & 50 & Tunisia & 52.7 & 85 & Guinea & 31.3 \\
\hline 16 & Japan & 80.7 & 51 & Colombia & 52.3 & 86 & Angola & 30.5 \\
\hline 17 & Sweden & 80.2 & 52 & Egypt & 51.6 & 87 & Mali & 30.4 \\
\hline 18 & Greece & 79.7 & 53 & Kazakhstan & 51.1 & 88 & Burkina Faso & 30.2 \\
\hline 19 & Italy & 79.1 & 54 & Jordan & 50.6 & 89 & Cambodia & 30.0 \\
\hline 20 & United Kingdom & 79.0 & 55 & Vietnam & 50.4 & 90 & Rwanda & 29.8 \\
\hline 21 & South Korea & 77.8 & 56 & El Salvador & 50.3 & $=91$ & Niger & 29.2 \\
\hline 22 & Israel & 77.7 & $=57$ & Ecuador & 50.0 & $=91$ & Mozambique & 29.2 \\
\hline 23 & Czech Republic & 73.5 & $=57$ & Honduras & 50.0 & 93 & Senegal & 28.8 \\
\hline 24 & Poland & 72.3 & 59 & Morocco & 49.3 & 94 & Sierra Leone & 28.7 \\
\hline 25 & Hungary & 70.7 & 60 & Guatemala & 48.2 & 95 & Zambia & 28.5 \\
\hline 26 & Chile & 68.9 & 61 & Dominican Republic & 48.1 & 96 & Sudan & 27.6 \\
\hline 27 & Slovakia & 68.8 & 62 & Sri Lanka & 47.4 & 97 & Togo & 27.5 \\
\hline 28 & Saudi Arabia & 68.7 & 63 & Philippines & 47.1 & 98 & Malawi & 27.3 \\
\hline 29 & Russia & 68.3 & 64 & Indonesia & 46.8 & 99 & Tanzania & 26.8 \\
\hline 30 & Mexico & 67.7 & 65 & Bolivia & 45.2 & 100 & Ethiopia & 26.4 \\
\hline 31 & Brazil & 67.6 & 66 & India & 45.0 & 101 & Madagascar & 26.3 \\
\hline 32 & Argentina & 64.0 & 67 & Azerbaijan & 44.4 & 102 & Haiti & 24.5 \\
\hline$=33$ & Malaysia & 63.9 & 68 & Ghana & 43.1 & 103 & Burundi & 22.9 \\
\hline$=33$ & Uruguay & 63.9 & 69 & Nicaragua & 42.7 & 104 & Chad & 20.2 \\
\hline 35 & Costa Rica & 63.8 & 70 & Syria & 42.0 & 105 & Congo (Dem. Rep.) & 18.4 \\
\hline
\end{tabular}

